\title{
A Study on The Application of Material Resource Planning, Vendor Managed Inventory And Just in Time Techniques For Procurement of Stents And Pacemakers in A Tertiary Care Institute.
}

\author{
Dr.K.V.Krishna Reddy ${ }^{1}$ Dr.Siddarth Sai ${ }^{2}$ Dr.Rakesh Prabhu ${ }^{3}$ \\ ${ }^{l}$ Asst Professor, Dept of Hospital Administration, NIMS \\ ${ }^{2,3}$ Senior Resident, Dept of Hospital Administration, KIMS
}

\section{Introduction}

Heath care demand and supply cannot therefore, be left to be regulated solely by the invisible hand of the market. Nor can it be established on considerations of utility maximizing conduct alone ${ }^{1}$. Each area of a hospital has specific and unique material and supply need creating a requirement in these facilities for supply management system that can provide the necessary supplies when needed Materials management is an important issue for healthcare systems because it influences clinical and financial outcomes ${ }^{2}$. Hospital materials management (HMM) also involves the clinical sphere of healthcare service performance ${ }^{2}$. It is conceivable to suppose that the main cause of inefficiency is the existence of hidden stocks to avoid stock-outs ${ }^{3}$, which would be more politics- and experience- rather than data-driven ${ }^{4}$

MRP is a scientific method of planning for arriving at time phased requirement of materials for meeting demand at the stipulated time. Sometimes this is also referred as dependent demand inventory system ${ }^{7}$ Hospitals are searching continuously for innovative ways to contain costs without sacrificing quality and meet the patients' needs. One successful solution has been the adoption of JIT manufacturing systems which involve many functional areas of a company such as manufacturing, engineering, marketing, and purchasing. JIT concepts have successfully been implemented in manufacturing organizations. There is a reasonable consensus among researchers that JIT is a useful approach for reducing costs and improving quality and can be applied to service environments also ${ }^{8}$. JIT focuses on the process and not on the product. It can therefore be applied to any group of processes whether manufacturing or service. The philosophy behind JIT is continuous improvement of processes. The ultimate goal of JIT is to attack waste. This goal can be achieved by eliminating non value added services.

Vendor Managed Inventory ${ }^{7}$ : In the traditional replenishment process, the customer has to create an order for the vendor at every step in the supply chain. The customer does not give prior notification of requirements, which means that the vendor is compelled to store safety stock that acts as a 'buffer' for all eventualities. The customers also have safety stock available of the same items as a protective mechanism in case they do not receive the required stock. This procedure leads to a larger amount of stock in the entire goods supply chain and, paradoxically, to a reduced level of customer service and a poorer response level.

\section{Need for the Study}

In order to achieve a comprehensive image of the HMM process and potential ways of exploiting IT to enable an efficient reengineering of this supply chain, reducing healthcare costs without affecting the quality of care Cardiology department contributes a major share to the revenue generated by the hospital. Most of the revenue generated by the department is due to the procedures performed in the cath lab.

\section{Objectives:}

1. Application of MRP methods to fix inventory levels for Vendor managed inventory.

\section{Methodology}

The study was carried out in the Cath lab stores of Nizam's institute of medical sciences, a tertiary care teaching hospital

A retrospective study of the data of cath lab stores during the period of April 1, 2015 to March 31, 2016 was done.

The following information was gathered from the stock records.

* Opening \& closing balance of stock

* Issues \& Receipts

* Price of individual items 
Data collected was entered and analyzed in Microsoft Excel.

\section{Observations \& Analysis:}

MRP is a forecasting technique which gives an idea about the estimated demand. The material requirement planning concept can be conveniently applied for procurement and stocking of stents of different companies and variants as they are regularly consumed.

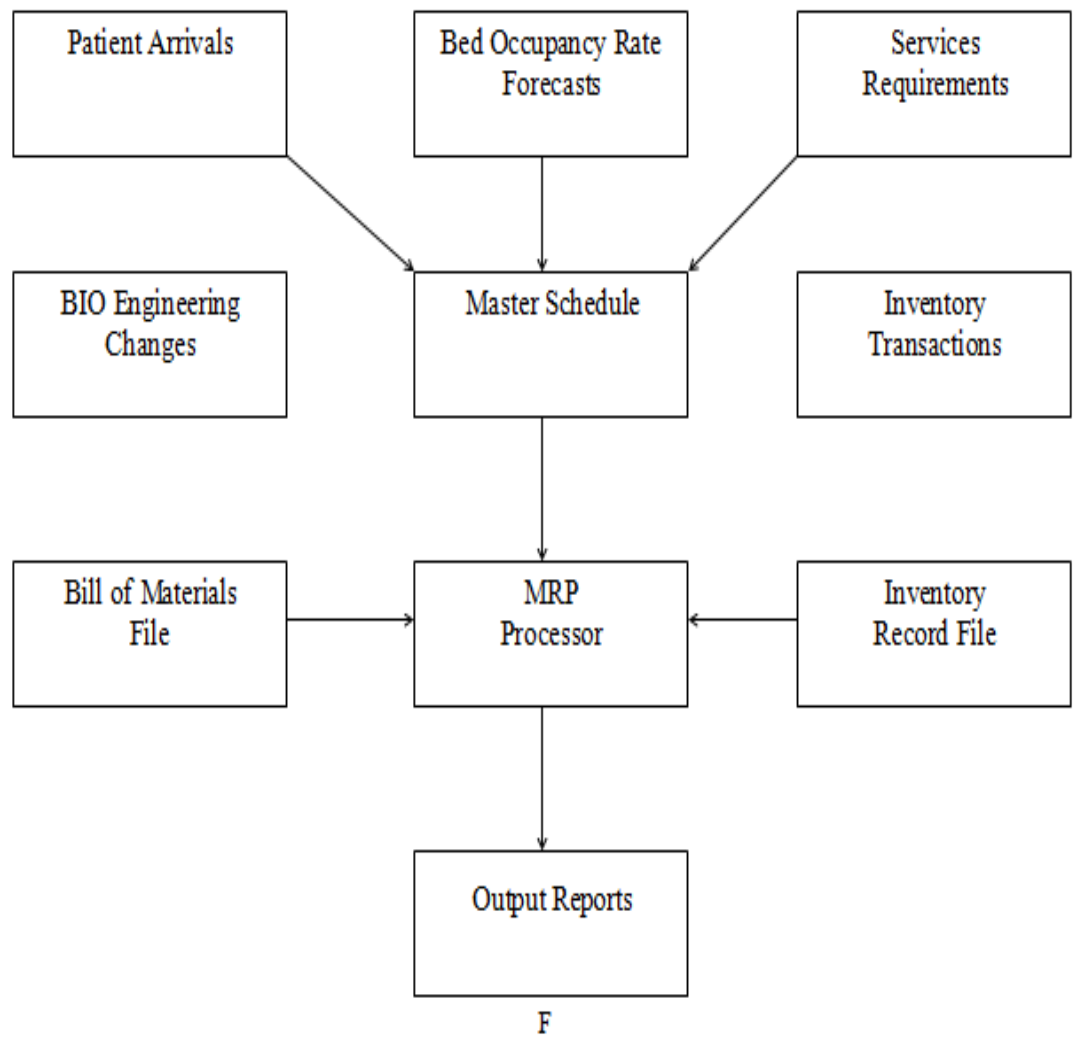

The following data was collected

\begin{tabular}{|l|l|}
\hline Year & Cardiology admissions \\
\hline $2013-14$ & Admissions \\
\hline $2014-15$ & 6954 \\
\hline $2015-16$ & 6877 \\
\hline
\end{tabular}

On an average there are 550 admissions per month in the cardiology dept. Techniques, such as Material Requirements Planning (MRP), which have been well established in manufacturing industries, have to be modified for use in healthcare MRP calculates the requirement of materials and schedules of supply demand pattern. It helps in determining when to buy and what frequency to buy. The prerequisite for MRP are master production schedules, bill of materials, inventory status records. MRP inputs covers master production schedules, production structure file or bill of materials file, and inventory records file. Structure of a material requirement planning (MRP) system comprises of revenue forecasts, patient arrivals, master schedule, engineering changes, inventory transactions, and inventory record files. If hospitals are to survive in the competitive environment, MRP is a good system for healthcare Materials Management. MRP as a guide in Hospital Material Requirement Planning (HRMP) system can be developed. The need to develop these standard material requirements will act as spring board for improved communication between materials managers and clinical managers and will also accelerate all parties understanding of interrelated nature of everyone's contributors to direct patient care. Material Requirement Planning (MRP) refers to systems that keep track of requirements and plan operations of the hospital in discrete time intervals. Usually the term includes explosion of net requirement on subordinate items. Computer support is the basic requirement to operate system, even in smaller hospitals. With continuing expansion of the microcomputer and personal computer markets, many of them now operate in online, real-time environment. Standardized material requirements are established for each 
diagnosis and procedure at each hospital. As projected admissions of patients and surgery cases are scheduled, the computer network generates lists of required materials. The lists so generated are compared to stock on hand and on order quantities and the required purchase orders for replenishment of stocks are generated automatically by the system? .

Cath lab procedures

\begin{tabular}{|l|l|l|l|l|}
\hline Procedure & $2013-14$ & $2014-15$ & $2015-16$ & Avg /day \\
\hline $\begin{array}{l}\text { Ad Hoc Coronary } \\
\text { Angioplasty }\end{array}$ & 188 & 179 & 240 & 0.7 \\
\hline $\begin{array}{l}\text { Cardiac } \\
\text { Catheterization }\end{array}$ & 275 & 298 & 344 & 0.9 \\
\hline Coronary angiogram & 3552 & 3520 & 3534 & 9.7 \\
\hline Direct stenting & 201 & 152 & 120 & 0.3 \\
\hline PTCA & 469 & 877 & 778 & 2.2 \\
\hline $\begin{array}{l}\text { Peripheral } \\
\text { angioplasty }\end{array}$ & 96 & 117 & 129 & 0.3 \\
\hline Renal angioplasty & 21 & 29 & 29 & 0.07 \\
\hline
\end{tabular}

Stents are maintained on consignment basis. The inventory carrying costs are borne by the vendor which eventually is passed on to customer or hospital, In the event of adopting vendor managed inventory no such costs will occur.

\section{Just in Time}

A lot of research papers ${ }^{9-15}$ have been reported on this issue which has suggested the concept of JIT purchasing and stockless programs in materials management of healthcare operations ${ }^{16,17}$ it has been said that although the characteristics of service systems vary from a manufacturing system but JIT techniques can be applied to service environments also JIT is short form of 'Just in Time'. This was originally introduced in Toyoto production system for the purpose of eliminating waste.

- This system is aimed at regulating flow process, the right parts needed in assembly reach the assembly line at the time they are needed and only in the quantity needed.

- This system is for minimizing inventory and in turn that leading to reduction in unnecessary wastage of space for storing and cost locked up in inventory, waste of machine hours, man hours and material handling time due to over production etc

- The operating method of the above system is 'Kanban'. Kanban is nothing but a tag or a piece of paper which contains all relevant information, part number, description, process area used, time of delivery, quantity available, quantity delivered, production quantity etc.

- This is used within the plant in operation area i.e. from stores or previous production area to the supply area and outside the plant with the vendors.

- According to Taichi Ohiino this is an idea developed from super market and its operating system.

Pacemakers, ASD, VSD devices are purchased using the JIT (just in time) concept .Pace makers demand is low and erratic. As and when demand arises it is procured from the local distributors who maintain the stock for all the hospitals in twin cities.The consumption of pace makers of different specifications are procured .The details of consumption are shown in annexure no 6 . Since the pace makers are not regularly used and are available with the suppliers as and when required from ex stock.. Hence it is advisable to adopt Just in time procurement concept.As an abundant caution the hospital can give a letter of intent showing the forecasted demand so that supplier can maintain stocks. Past experience shows there are no abnormal delays affecting the patient care. Hence it is suggested that just in time concept can be adopted without holding inventories of costly items like pacemakers.

Consumption of Stents

\begin{tabular}{|l|l|l|l|l|l|l|l|}
\hline Item & $\begin{array}{l}\mathbf{2 0 1 3 -} \\
\mathbf{1 4}\end{array}$ & $\mathbf{2 0 1 4 - 1 5}$ & $\begin{array}{l}\mathbf{2 0 1 5} \\
\mathbf{1 6}\end{array}$ & & Avg & $\begin{array}{l}\text { Avg } \\
\text { Day }\end{array}$ & Per \\
\hline XIENCE -V STENT & 115 & 395 & 363 & 291.0 & 0.8 \\
\hline $\begin{array}{l}\text { ENDEAVOR } \\
\text { STENTS }\end{array}$ & 281 & 100 & 341 & 240.7 & 0.7 \\
\hline INTEGRITY STENTS & 0 & 24 & 166 & 63.3 & 0.2 \\
\hline BIOMIME STENT & 160 & 354 & 143 & 219.0 & 0.6 \\
\hline TAXUS STENTS & 10 & 11 & 141 & & 54.0 & 0.1 \\
\hline
\end{tabular}


A Study On The Application Of Material Resource Planning, Vendor Managed ...

\begin{tabular}{|c|c|c|c|c|c|}
\hline ENDEAVOR SPRINT STENTS & 54 & 73 & 132 & 86.3 & 0.2 \\
\hline SUPRALIMUS STENTS & 182 & 50 & 115 & 115.7 & 0.3 \\
\hline LUMINEXX STENT & 35 & 45 & 92 & 57.3 & 0.2 \\
\hline EXPRESS VASCULAR STENT & 0 & 6 & 85 & 30.3 & 0.1 \\
\hline PROMUS ELEMENT STENTS & 32 & 35 & 81 & 49.3 & 0.1 \\
\hline DRIVER STENT & 85 & 115 & 63 & 87.7 & 0.2 \\
\hline $\begin{array}{lll}\text { COROFLEX } & \text { BLUE } & \text { STENTS( } \\
\text { BMS ) } & & \end{array}$ & 85 & 74 & 60 & 73.0 & 0.2 \\
\hline BX-SONIC STENT & 0 & 1 & 27 & 9.3 & 0.0 \\
\hline PATRIOT STENT & 109 & 131 & 24 & 88.0 & 0.2 \\
\hline YUKON STENTS & 201 & 83 & 16 & 100.0 & 0.3 \\
\hline COROFLEX BLUE STENTS & 43 & 82 & 11 & 45.3 & 0.1 \\
\hline DRIVER STENT ( BMS CE ) & 0 & 25 & 11 & 12.0 & 0.0 \\
\hline PRECISE STENT & 19 & 9 & 10 & 12.7 & 0.0 \\
\hline LIBERTE STENT & 30 & 2 & 7 & 13.0 & 0.0 \\
\hline RESISTANT STENT & 0 & 0 & 5 & 1.7 & 0.0 \\
\hline COBALT+C \& MINI STENT & 0 & 21 & 3 & 8.0 & 0.0 \\
\hline $\begin{array}{lll}\text { EXPRESS } & \text { VASCULAR } & \text { SD } \\
\text { STENT } & & \\
\end{array}$ & 0 & 12 & 3 & 5.0 & 0.0 \\
\hline DRIVER INTEGRITY STENTS & 0 & 1 & 2 & 1.0 & 0.0 \\
\hline PROSTAR PLUS STENT & 0 & 37 & 2 & 13.0 & 0.0 \\
\hline SONIC STENT & 7 & 2 & 2 & 3.7 & 0.0 \\
\hline BVS ABSORB STENT & 0 & 0 & 1 & 0.3 & 0.0 \\
\hline COBAL+C STENT & 73 & 74 & 1 & 49.3 & 0.1 \\
\hline MICRO DRIVER STENT & 0 & 0 & 1 & 0.3 & 0.0 \\
\hline PRESSURE WIRE & 51 & 39 & 1 & 30.3 & 0.1 \\
\hline ASSURANT COBALT STENT & 11 & 1 & 0 & 4.0 & 0.0 \\
\hline BRIDGE ASSURANT STENT & 1 & 1 & 0 & 0.7 & 0.0 \\
\hline CHROMAXX STENT & 32 & 21 & 0 & 17.7 & 0.0 \\
\hline CLEAR FLEX STENT & 1 & 13 & 0 & 4.7 & 0.0 \\
\hline COROFLEX PLEASE & 77 & 41 & 0 & 39.3 & 0.1 \\
\hline CYHPHER STENTS & 71 & 121 & 0 & 64.0 & 0.2 \\
\hline DELIGHT STENTS & 98 & 63 & 0 & 53.7 & 0.1 \\
\hline $\begin{array}{l}\text { DRIVER STENT } \quad(\quad \text { Rapid } \\
\text { Exchange FDA })\end{array}$ & 18 & 0 & 0 & 6.0 & 0.0 \\
\hline ENDURANT STENT & 2 & 0 & 0 & 0.7 & 0.0 \\
\hline EXPORT CATHETER & 35 & 15 & 0 & 16.7 & 0.0 \\
\hline FLUENCY PLUS STENT & 2 & 0 & 0 & 0.7 & 0.0 \\
\hline GENESIS STENT & 41 & 5 & 0 & 15.3 & 0.0 \\
\hline JANUS STENT & 21 & 0 & 0 & 7.0 & 0.0 \\
\hline LIFE STENT & 0 & 2 & 0 & 0.7 & 0.0 \\
\hline OPTIMA STENT & 0 & 5 & 0 & 1.7 & 0.0 \\
\hline PALMAZ BARE STENT & 1 & 0 & 0 & 0.3 & 0.0 \\
\hline PALMAZ BLUE STENT & 35 & 38 & 0 & 24.3 & 0.1 \\
\hline PLAMAZ AORTIC STENT & 1 & 0 & 0 & 0.3 & 0.0 \\
\hline $\begin{array}{ll}\text { RESOLUTE } & \text { INTEGRITY } \\
\text { STENTS } & \\
\end{array}$ & 0 & 21 & 0 & 7.0 & 0.0 \\
\hline
\end{tabular}


A Study On The Application Of Material Resource Planning, Vendor Managed ...

\begin{tabular}{|l|l|l|l|l|l|l|l|}
\hline SATIN FLEX STENT & 42 & 0 & 0 & & 14.0 & 0.0 \\
\hline $\begin{array}{l}\text { STAINLESS STL. TECHNIC+ } \\
\text { STENT }\end{array}$ & 45 & 0 & 0 & & 15.0 & 0.0 \\
\hline SUPRA-CORE STENT (DES-CE) & 0 & 15 & 0 & 5.0 & 0.0 \\
\hline VALIANT THORACIC STENTS & 5 & 0 & 0 & & 1.7 & 0.0 \\
\hline ZILVER FLEX STENT & 0 & 3 & 0 & & 1.0 & 0.0 \\
\hline
\end{tabular}

\section{Consumption of Pacemakers}

\begin{tabular}{|c|c|c|c|c|c|}
\hline Item & 2013-14 & 2014-15 & 2015-16 & Avg & Avg Per Day \\
\hline Aicd Dual Chamber Pacemaker & 5 & 2 & 2 & 3.0 & 0.01 \\
\hline Angio Guard & 14 & 8 & 8 & 10.0 & 0.03 \\
\hline Asahi Corsair & 0 & 3 & 7 & 3.3 & 0.01 \\
\hline Asd Device & 12 & 11 & 12 & 11.7 & 0.03 \\
\hline Asd Device Closure With Kit & 3 & 0 & 1 & 1.3 & 0.00 \\
\hline Asd Device With Delivery Kit & 0 & 0 & 5 & 1.7 & 0.00 \\
\hline Asd Occluder Device & 2 & 0 & 7 & 3.0 & 0.01 \\
\hline Bipolar Pacing Lead & 0 & 1 & 1 & 0.7 & 0.00 \\
\hline Crt Pacemaker & 13 & 8 & 10 & 10.3 & 0.03 \\
\hline Dddr Pacemaker & 32 & 36 & 35 & 34.3 & 0.09 \\
\hline Dior Balloon & 6 & 3 & 0 & 3.0 & 0.01 \\
\hline Dual Chamber Aicd & 0 & 1 & 2 & 1.0 & 0.00 \\
\hline Duct Occluder (Pda Device) & 0 & 0 & 1 & 0.3 & 0.00 \\
\hline Ivc Filter & 7 & 4 & 16 & 9.0 & 0.02 \\
\hline Moma Ultra Device & 1 & 0 & 0 & 0.3 & 0.00 \\
\hline Pacemaker Lead & 4 & 5 & 2 & 3.7 & 0.01 \\
\hline Pacemaker Vvir & 1 & 0 & 0 & 0.3 & 0.00 \\
\hline Pacing Lead & 1 & 2 & 1 & 1.3 & 0.00 \\
\hline Pda Device & 11 & 12 & 6 & 9.7 & 0.03 \\
\hline Pda Occluder & 2 & 4 & 1 & 2.3 & 0.01 \\
\hline Screwing Lead (St.Jude) & 0 & 0 & 1 & 0.3 & 0.00 \\
\hline Single Chamber Aicd & 0 & 0 & 1 & 0.3 & 0.00 \\
\hline Single Lead Pacemaker (Vvir) & 0 & 0 & 1 & 0.3 & 0.00 \\
\hline Ventricle Lead & 0 & 0 & 1 & 0.3 & 0.00 \\
\hline Valiant Thoracic Stents & 5 & 0 & 0 & 1.7 & 0.00 \\
\hline Vddr Pacemaker & 1 & 1 & 0 & 0.7 & 0.00 \\
\hline Vsd Device & 2 & 1 & 0 & 1.0 & 0.00 \\
\hline Vvir Pacemaker & 36 & 31 & 23 & 30.0 & 0.08 \\
\hline Asd Device Closer & 16 & 13 & 0 & 9.7 & 0.03 \\
\hline
\end{tabular}

\section{Items where JIT can be implemented}

\begin{tabular}{|l|l|l|l|}
\hline Item & Annual demand & Buffer stock & Price \\
\hline Cutting Balloons & 0 & 0 & 42263 \\
\hline Carotid sheaths & 0 & 0 & 1500 \\
\hline Pericardiocentesis kit & 0 & 0 & 10660 \\
\hline Atrial Septostomy catheter & 0 & 0 & 60770 \\
\hline Biopsy forceps & 1 & 1 & 22768 \\
\hline Bifurcation balloon & 1 & 1 & 18500 \\
\hline Snair kits & 2 & 1 & 15600 \\
\hline Septal Puncture needle & 3 & 1 & 5950 \\
\hline Carotid balloons & 4 & 1 & 7000 \\
\hline $\begin{array}{l}\text { PDA coil closure device with } \\
\text { delivery kit }\end{array}$ & 4 & 1 & 10150 \\
\hline Mullins sheaths & 5 & 1 & \\
\hline Microcatheters & 5 & 1 & 2449 \\
\hline PBAV balloons & 5 & 1 & 13860 \\
\hline PDA coils & 7 & 1 & 13394 \\
\hline Berman catheters & 9 & 1 & 6580 \\
\hline Angiomed syringes & 13 & 1 & 7000 \\
\hline INOUE balloon & 15 & 1 & 1450 \\
\hline
\end{tabular}




\section{Conclusion}

Application of Material Resource Planning, Vendor Managed Inventory and Just in Time techniques for procurement of stents and pacemakers in a tertiary care institute is the need of the hour and healthcare institutes should adapt to the latest investment management techniques.

\section{References}

[1]. Planningcommission.gov.in/reports/genrep/bkpap2020/26_bg2020.doc

[2]. Raffele lannone et al; Modelling hospitals materials management processes; International journal of engineering business management ;2013

[3]. de Vries J (2011) The shaping of inventory systems in health services: A stakeholder analysis. International Journal of Production Economics, 133(1),

[4]. Nicholson L, Vakharia AJ, Erenguc SS (2004) Outsourcing inventory management decisions in healthcare: Models and application. European Journal of Operational Research, 154, 271-290

[5]. Jarrett PG (1998) Logistics in the health care industry. International Journal of Physical Distribution and Logistics Management, 28(9), 741-772

[6]. Integrating the Healthcare Enterprise (2012) IHE Pharmacy. Technical Framework Supplement. Hospital Medication Workflow, Trial Implementation. http://www.ihe.net/Technical_Framework/upload/IH E_Pharmacy_Suppl_HMW.pdf [accessed 5 November 2012].

[7]. Handbook of material management for healthcare industry ; Dr. V. Venkat Reddy ; book under publication

[8]. Gupta AK ; JIT in healthcare, an integrated approach; International journal of advances in management and economics ; Vol 2 issue 1, Feb 2012

[9]. Dorene Lynch BS (1991) Just-in-time and stockless programs for hospitals: fad or trend. Hospitals Material Management Quarterly 12(4):17-21.

[10]. Berling RJ, Geppi JJ (1989) Hospitals can cut materials cost by managing supply Pipeline.J.the Health Care Financial Management Association 43(4): 19

[11]. DeJohn P (1998) New materials specialists add personal touch to supply chain. Hospitals materials Management 23(6):1-13.

[12]. Griesler DS, Aggarwal, SC (1987) Job status and satisfaction of hospital material managers", Hospitals Material Management Quarterly 8(3):66-75.

[13]. LaPlante A (1992) Inventory solutions from Henry Ford's day is just as valid today, Evanston hospital Corp.'s use of just-in-time inventory management techniques. InfoWorld 14(47):52.

[14]. Lynch Dorene (May 1991) Just-in-time and stockless programs for hospitals: Fad or Trend? Hospitals Materials Management Quarterly.

[15]. Noorda Roger W (2002) Professional paper: Lake Mead Hospital Conversion to Complete Delivery System. Master's degree in Public Administration University of Nevada Las Vegas, pp. 1-28

[16]. Inman RA, Mehra S (1991) JIT applications for service environments. Production and inventory Management Journal 32(3):16-21.

[17]. Yasin MM, Wafa MA, Small MH (2003) Organizational modifications to support JIT implementation in manufacturing and service operations. Omega, Int. J. Management Science, 31:213-26. 